Nowoczesne Systemy Zarządzania

Zeszyt 15 (2020), nr 1 (styczeń-marzec)

ISSN 1896-9380, s. 45-53

DOI: $10.37055 /$ nsz/132718

Modern Management Systems

Volume 15 (2020), No. 1 (January-March)

ISSN 1896-9380, pp. 45-53

DOI: $10.37055 / \mathrm{nsz} / 132718$
Instytut Organizacji i Zarządzania Wydział Bezpieczeństwa, Logistyki i Zarządzania

Wojskowa Akademia Techniczna

w Warszawie

Institute of Organization and Management Faculty of Security, Logistics and Management Military University of Technology

\title{
Military Leadership. Ukrainian Perspectives
}

\section{Przywództwo wojskowe. Perspektywa ukraińska}

\author{
Yurii Korniichuk \\ Korolov Zhytomyr Military Institute, Zhytomyr, Ukraine \\ korniy.yg@gmail.com, ORCID: 0000-0002-0699-3811 \\ Yevhen Starokon \\ Korolov Zhytomyr Military Institute, Zhytomyr, Ukraine \\ ksn_zvir@ukr.net, ORCID: 0000-0001-8833-0351 \\ Oleksandr Shkatula \\ Korolov Zhytomyr Military Institute, Zhytomyr, Ukraine \\ shkatula_a_p@ukr.net, ORCID: 0000-0003-0119-6167
}

\begin{abstract}
The article considers issues related to the formation of leadership in the Armed Forces of Ukraine. The practices and training programs for leaders, both in Ukraine and in its Armed Forces, are analyzed. Problems, obstacles and difficulties that arise in the process of forming a military leader are studied. Keywords: Armed Forces of Ukraine, leadership, leadership qualities.
\end{abstract}

Abstrakt. Artykuł rozważa kwestie związane z formowaniem przywództwa w Siłach Zbrojnych Ukrainy. Przeanalizowane są praktyki i programy szkoleniowe dla liderów, zarówno na Ukrainie, jak i w jej Siłach Zbrojnych. Badane są problemy, przeszkody i trudności powstające w procesie formowania dowódcy wojskowego.

Słowa kluczowe: Siły Zbrojne Ukrainy, przywództwo, cechy przywódcze. 


\section{Introduction}

One of the key aspects of Ukraine's modernization in the 21st century concerns the development of leadership skills for the chiefs at all levels, from school to the state service. There is a belief that this is a strategic condition for relevant governance in Ukraine, as it is a pivotal factor in reforming the state service, implementing administrative reform, defining and maintaining a Euro-oriented course of development of the Ukrainian state. A remarkable role in such process belongs to employees who should become leaders in the state service system, capable managers who are competent in the advanced management technologies and are able to quickly and effectively resolve social and administrative conflicts, successfully establish communication links of all levels and configurations, and those who have the ability to teach their subordinates to become leaders.

It is the leaders who must play a major role in the implementation of state reforms, be their implementators and leaders. The quality of leadership is the groundwork for the further success of both the state and its military structures. That is why the aim of the article is to study the process of training military leaders.

\section{Leadership development in Ukraine}

In order to develop leadership in Ukraine, a number of programmes aimed at forming leadership skills for the chiefs of intermediate command and staff level, and senior level have been introduced and successfully implemented. One of the related programmes is "The Leadership Development Programme", launched in 2010 by the Cabinet of Ministers of Ukraine, dated August 25, 2010 № 728 "On approval of the Procedure for organizing and conducting training for state officials of the first and second category by the School of Senior Level of the State Service" (Pro zatverdzhennia Poriadku orhanizatsii i provedennia..., 2010).

The Leadership Development Programme includes an orientation session and five educational modules which are "Leadership in Modern Public Administration", "Leadership and Team Building", "Leadership in Reform Process and Change Management", "Leadership in Human Resource Management", "Leadership and Building Effective Communication in the Structure of Public Administration"; they in turn are divided into training sessions and communicative activities for the development of senior level of state service.

The Programme objective is "...to assist participants in capacity building of personal leadership and developing knowledge, skills and habits for effective management in situations that require the use of leadership proficiency". During the first five years of the Programme implementation, more than five hundred state officials of the first and second categories became its participants (Zatverdzheno Prohramu rozvytku liderstva..., 2014). 
Along with that, Ukraine's military system, which has faced new challenges and threats, also desperately needs to form a military not only as a professional, but also as a leader for his subordinates. It should be noted that effort in this direction has been carried out since the beginning of the foundation of Ukraine's independence. However, only during last 5 years it has begun to acquire systematic character and take specific actions.

The first public mention of the problems of producing military leaders for the Armed Forces of Ukraine is found in 2011 in the speech Commander-in-Chief of the Armed Forces of Ukraine of that period, Chief of General Staff Hryhorii Pedchenko at the meeting with officers of the Lviv garrison. In May 2011, he determined that 2012 would be declared the Year of the Military Leader (Ofitser-lider - diisna potreba chy cherhovyi mif?, 2020).

However, the lack of a clear understanding of the concept of military leadership, and the fact that to produce military leadership qualities the formal-administrative approach was taken, according to which the officer was considered a leader only because he was a chief to his subordinates, hindered the process of forming a leader in the Armed Forces. For some time, the concept of "military leader" existed exclusively in articles, speeches, research works, etc. The Armed Forces of Ukraine regulations, the curricula of military educational institutions did not contain any references to the leaders training.

With the beginning of hostilities on the territory of Ukraine, the need to produce military leaders became very acute, which led to a real transformation in the content of military training. The first tangible steps were the training of junior commanders. With the increase of the role of a sergeant in the Armed Forces of Ukraine, with the introduction of the category of competent sergeants, and with the beginning of training of sergeants at Army Sergeant Majors colleges within the higher educational institutions a steady growth of leadership qualities of the NCO corps had begun.

In 2014, the course "Team Leadership" was conducted by the 51st Separate Mechanized Brigade of Operational Command North. The course programme is designed to prepare nominees for the positions of commanders of combat vehicles and mechanized units according to new methods. Special teaching staff from military educational institutions was involved in the course programme.

In 2016, a seminar on "The role and part of a sergeant and sergeant major in the organization of combat training in the military unit, ensuring and maintaining proper level of military discipline" being devoted to the formation of an effective sergeant corps was held at the Military Academy (Odessa) with the participation of sergeants and sergeant majors of the Armed Forces of Ukraine. Similar events took place in Dnipro and Chernihiv as part of all-army meeting of sergeants and non-commissioned officers in Kyiv. During the meeting, problematic issues that hinder the performance of functional tasks, as well as the perspectives for the formation of an effective sergeant corps were discussed. In the same year with the assistance of the Office of Defense Cooperation of the USA in at a separate marine corps brigade there was a course 
of training of the Ukrainian Marines in leadership. The course lasted two weeks, during which Ukrainian soldiers were introduced to the role and responsibilities of the Marines sergeants. During the training, Ukrainian soldiers applied the acquired knowledge in practice, and exchanged their own experience with foreign instructors.

In 2016, the Order of the Ministry of Defense №151 of 18.03.2016 “On approval of amendments to the Conception for the development of professionalism of sergeants and sergeant majors of the Armed Forces of Ukraine" defined the tasks of forming an effective sergeant corps as "improving the training system of sergeants and sergeant majors in order to enhance their excellence, proficiency level, and leadership qualities..." (Nakaz Ministerstva oborony Ukrainy № 151, 2016).

During 2014-2017, the Sergeant Training Centres of the Armed Forces of Ukraine were established specializing by the branches of the armed forces, namely: 197th Sergeant Training Centre in Desna was founded for Land Forces; 203rd Sergeant Training Centre in Vasylkiv - for Air Force; 202nd Sergeant Training Centre in Mykolayiv - for Navy. A leadership course for sergeants has been introduced in the training centres. During the training cycle, which is three weeks, one Centre is able to train from 100 to 250 servicemen. The trainings are conducted by Ukrainian instructors who have taken a number of leadership courses according to NATO standards. "Band Leadership Training" has been created in the training centres, which contribute to the development of leadership qualities and the growth of the professionalism of the sergeant corps. From 2017, the leadership training of sergeants becomes multilevel.

In higher military educational institutions, the work on the formation of leadership qualities of future officers is increasing. Thus, in 2018, the National Ground Forces Academy launched experimental "Leadership Courses". Over a period of 12 months, students who have an educational qualification level not lower than «bachelor» study military affairs. The training comprises 4 stages and consists of the following drills: basic combat training course, individual and professional training, individual and collective and joint training. Upon completion of the course, graduates receive the qualification of tactical level management officer and the military rank of second lieutenant.

Ivan Chernyakhovsky National Defense University of Ukraine introduces the course of Military Leadership in the educational process, during which special attention is paid to the study of democratic values founded in The NATO Code of Conduct, namely promoting the highest levels of trust between its members and the formation of integrity, loyalty, accountability, impartiality, and professionalism, regardless of gender.

In 2019, by the Law of Ukraine № 205-IX of October 17, 2019 “On Amendments to Certain Legislative Acts of Ukraine Concerning the Performance of Military Duty and Military Service" the Internal Service Statute for the first time contains the responsibilities to "improve leadership qualities" of the officials (Pro vnesennia zmin do deiakykh zakonodavchykh aktiv Ukrainy..., 2019). 
Currently, the main forms of training leaders in the Ukrainian army are:

- leadership training of NCO staff (training courses of four levels: basic, intermediate, advanced and higher);

- leadership training of cadets in higher military educational institutions (including such academic subjects as Leadership in professional activities, Schools of Leadreship, courses, trainings, seminars);

- leadership training of junior officers ("Management and leadership in the military unit" educational courses, leadership courses, seminars, trainings),

- leadership training of students of the Ivan Chernyakhovsky National Defense University of Ukraine ("Military Leadership" and "Strategic and Operational Leadership" courses, round table discussions).

Officers have been studying to be military leaders at Korolov Zhytomyr Military Institute in Zhytomyr (hereinafter referred as ZMI) since April 2012. Since then, the "School of Leaders of ZMI" has been operating. The purpose of the School is to teach cadets the skills to implement leadership behavior in professional activities, their own lives, and interaction with others.

On December 14, 2017, the Zhytomyr Military Institute hosted an International Scientific and Practical Conference on Socio-psychological Portrait of a Military Professional. In the course of the conference a wide-ranging discussion took place around the issue of Leadership as a Relevant Feature of a Modern Military Professional. It was attended by representatives of foreign partner countries:

- Military University of Technology in Warsaw, Republic of Poland;

- General Jonas Zemaitis Military Academy of Lithuania;

- Czech Republic defense sector staff.

In a period of 13 to 16 November, 2018, the representatives of the delegation of the Republic of Poland visited Zhytomyr Military Institute as participants of task force meeting and shared their experience in training military and civilian specialists at the Military and Technical Academy of Jarosław Dąbrowski in Warsaw, Republic of Poland. The focus was on the organization of the process of formation of leadership traits and competencies of the cadets of the Academy.

During 2017-2019, a series of scientific and methodological seminars was held within the DEEP program at Zhytomyr Military Institute, the purpose of which was to exchange experience in using advanced pedagogical methods of forming leadership qualities of cadets. The seminars were organized and conducted by Tony R. Mullis (USA) and Iryna Lysychkina (Ukraine), the expert instructors of the Working Group on Educational Development of the Partnership for Peace Consortium.

On March 26-28, 2019, Piotr Ciężki, the coordinator for international cooperation, and Janusz Rubinski, the representative of the Military and Technical Academy of Jarosław Dąbrowski in Warsaw, Republic of Poland, held a series of briefings and workshops to discuss new methods and concepts of teaching leadership at Ukrainian higher military educational institutions. 
The primary need to demonstrate new approaches in the leadership of the Armed Forces of Ukraine has literally forced all levels of military command to apply to leadership. Leadership in the 21st century is the key to the success of any organization, including the military.

\section{Difficulties and obstacles to forming a military leader}

At present stage of development of the Armed Forces of Ukraine, we need to clearly understand what prevents us from moving forward, quickly and efficiently form military leaders at all hierarchical levels of the military structures and at all command levels. To be aware of our problems is the first step to overcoming them.

Therefore, it is necessary to study the obstacles and difficulties encountered in the formation of the military elite, namely, military leaders.

The first thing to take cognizance of is that we live in a psychologically illiterate country. This fact affects all aspects of military leadership without exception. No one doubts that leadership is based on psychological phenomena. They are rather numerous and diverse. There is no need to list them. However, practice shows that most commanders are arrogant about many psychological recommendations. Although the laws of psychology, like any law, act inevitably. Ignoring them leads to many commander's problems. It should also be mentioned that due to psychological illiteracy, psychology in a military institute is not even a secondary academic subject because there is very few academic hours to study it.

Leadership, as a value phenomenon, is formed for a length of time and in a complicated manner. The basic values of a person are formed before entering the military service. In fact, commanders are now re-educating their subordinates, because not all servicemen are ready to demonstrate the necessary moral qualities and norms in the process of military service. The process of reformatting the human axiological sphere raises many more questions than we have answers to.

If there are many rules, there is little space for initiative, creativity and innovation. The army is bureaucratic in form. This fact shows both its strength and weakness. From the psychological aspect it is very difficult for a cadet, a sergeant and an officer to demonstarte leadership skills under such conditions. Taking responsibility, proposing a new approach to solving a problem, showing activity and initiative are the elements of behavior that can not always be assessed by superior officers in an explicit and positive way. This restrains our military from showing and developing leadership.

Leadership is an extremely complex phenomenon, which is not completely clear to those scientists who have dedicated their research to this notion. Moreover, almost all the conceptions of leadership have been designed long ago. The engineer, who stralled through the factory at the beginning of the 20th century, was an absolute 
authority for the workers, who could only put a cross in front of their last name due to their writing skills, and his leadership was evident. Nowadays we have different social, economic, educational, and informational conditions. They cannot even be compared to the conditions when leadership theories emerged and were developed. In this regard, the joint scientific and research work of our institutions to study the phenomenon of the modern leader and leadership in military service is probably still insufficient.

Does the commander benefit from leadership? For most commanders it is much simpler, more familiar and easier to use administrative control levers. They do not realize the unconditional benefits of leadership for command. The primary task for now is to change the consciousness of commanders, to show the evident advantages of leadership, to force them to leave the zone of "administrative management comfort".

When using leadership as control tool commanders cannot leave the usual comfort zone due to fact that it requires significant physiological and psychological effort at the initial stage. Constant self-control, self-regulatory function, intense intellectual activity in response to a number of not always positive challenges of military service requires a lot of vital energy, time and psychological, pedagogical and managerial skills. It is difficult.

The fact that leadership at the grassroots level is the least studied phenomenon hinders effective teaching of leadership in military institutions. As a rule, many educational materials of different educational institutions, which we had an opportunity to familiarize with during various events, were strictly about leadership. That is not enough for now. Concretization and substantiation of leadership competencies at different levels of management would allow us to move to a more specific and substantive training of future officers.

Leadership at the grassroots level requires strong military and humanitarian training. In fact, leadership competencies, which are traditionally classified as humanitarian, refer to military professional ones. Specialty departments should be interested in such additional educational subjects as andragogy, microsociology, professional communication, negotiation theory, conflict studies, management, extreme communication and more to be the basis of leadership. The cadets would be able to apply the acquired knowledge in these educational subjects in practice during training and practical classes in the specialty. This seems to be logical.

We could make significant progress to produce a military leader by initiating the study of leadership technologies. The simplest definition of such technology could be as follows. These are the most psychologically appropriate, meaningful, practised, formalized and effective actions of the officer in a specific management situation to achieve the goal. On one hand, military service is an endless number of situations. On the other hand, most situations concerning military service are typical and limited in number. Having mastered, for example, 20 leadership technologies, an officer will be able to use a leadership approach to find ways to solve an unfamiliar situation. 
Such an approach would be more effective than the others, because 100 percent of our graduates need to demonstrate leadership behavior. In this case, knowledge of leadership technologies would allow the graduates to do so.

The formation of leadership is procrastinated by the lack of conditions for the education of leaders in military educational institutions. We try to form leadership based on the requirements of outdated statutes and other legislation. Here is an example. A cadet of a military institute is never considered to be a conscript. From the first moment after crossing the checkpoint, he must feel like an officer, think like an officer, and act like an officer. For now, we hope for a miracle, when the cadet's consciousness will change dramatically after garduation. In practice, such changes take place slowly and toughly, resulting in various complications in the spheres of daily life and work.

Another obstacle is inability to adapt the socio-cultural and ethno-national features of the Ukrainian army of foreign methods. Our society and the Armed Forces in particular are the least willing to accept behavioral methods of influencing both people and the organization of activities in general.

The lack of a genuine leadership environment today is a significant obstacle to training leaders. In fact, the community of leaders in the Armed Forces of Ukraine is just being formed.

An officer's organizational leadership should be based on leadership in his own life. This statement does not require proof. You cannot inspire your subordinates to achieve a goal when you are a disorganized person without any clear personal goals and values unable to organize your own activities, and so on. From the first year of study cadets should be taught the techniques of planning their activities, self-organization, self-control, goal setting, and time management. After having formed a leader in his private life, we have a chance to produce a good military leader.

It should be emphasised on the existence of toxic leadership traditions in many departments. It is a serious problem. Its solution should be based on the exemplary morality of commanders and the scientific and pedagogical staff of military educational institutions, the implementation of integrity policy, and service leadership of all commanders.

From our perspective, we have considered the most relevant obstacles and difficulties to form military leaders. Certainly, this is not a complete list. Nevertheless, we hope we can overcome them all.

\section{Conclusions}

In recent years, the Armed Forces of Ukraine have done tremendous work to change the minds of commanders about leadership. Many scientific conferences, round table discussions, seminars and trainings on the application of leadership 
in military service have been held. Military institutes, military universities, and academies are actively implementing leadership programmes to the Officer Education System. A number of leadership courses have been launched not only for officers but also for sergeants. We have been doing a lot. However, we would like to have much better results from the efforts of a large number of people who have joined this work.

\section{REFERENCES}

[1] Zatverdzheno Prohramu rozvytku liderstva-2014 / Kabinet Ministriv Ukrainy / ofitsiinyi veb sait. URL : https://www.kmu.gov.ua/news/247032734 (accessed on: 03.02.2020).

[2] Ofitser-lider - diisna potreba chy cherhovyi mif? / Internet-portal / URL: https://gurt.org. ua/blogs/\%D0\%9E\%D0\%BB\%D0\%B5\%D0\%B3\%20\%D0\%91\%D0\%BE\%D0\%B9\%D0\%BA$\% \mathrm{D} 0 \% \mathrm{BE} / 811 /$ (accessed on: 23.01.2020).

[3] Pro zatverdzhennia Poriadku orhanizatsii i provedennia Shkoloiu vyshchoho korpusu derzhavnoi sluzhby treninhiv dlia derzhavnykh sluzhbovtsiv pershoi - druhoi katehorii / Postanova Kabinetu Ministriv Ukrainy; Poriadok vid 25.08.2010 № 728. https://zakon.rada.gov.ua/laws/ show/728-2010-\%D0\%BF.

[4] Pro vnesennia zmin do deiakykh zakonodavchykh aktiv Ukrainy shchodo vykonannia viiskovoho oboviazku ta prokhodzhennia viiskovoi sluzhby / Zakon Ukrainy vid 17.10.2019 №205-IX: Internet-portal. Elektronni dani. Kyiv : Verkhovna Rada Ukrainy URL: https://zakon.rada.gov. ua/laws/show/205-20].

[5] Nakaz Ministerstva oborony Ukrainy № 151 vid 18.03.2016 «Pro zatverdzhennia Zmin do Kontseptsii rozvytku profesiinoho serzhantskoho i starshynskoho skladu Zbroinykh Syl Ukrainy» / rokiv / Ministerstvo oborony Ukrainy / ofitsinyi veb sait. URL: https://www.mil.gov.ua/ministry/ normativno-pravova-baza/nakazi-ministra-oboroni- ukraini/nakazi-ministerstva-oboroni-ukraini-za-2016-rik.html. 